\title{
Наукометричний аналіз публікаційної активності науковців ДУ «Інститут ендокринології та обміну речовин ім. В.П. Комісаренка НАМН України» за даними наукометричної бази даних Web of Science
}

М.Д. Тронько, I.П. Пастер

ДУ «Інститут ендокринології та обміну речовин ім. В.П. Комісаренка НАМН України»

Резюме. Мета - наукометричний аналіз публікаційної активності науковців ДУ «нститут ендокринології та обміну речовин ім. В.П. Комісаренка НАМН України» (далі - Інститут) за даними наукометричної бази даних Web of Science. Матеріал і методи. Метод дослідження - наукометричний аналіз наукових публікацій за даними наукометричної бази даних Web of Science. Об'єктом дослідження були всі публікації науковців Інституту за даними Web of Science Core Collection, а предметом дослідження - кількість публікацій, індекс Хірша (h-index), кількість бібліографічних посилань на публікації та кількість статей із бібліографічними посиланнями на публікації (загальна кількість і кількість без самоцитування). Результати. Станом на 01.11.2019 року в штаті Інституту налічувалося 79 науковців, із них 18 із науковим ступенем доктора наук, 41 - кандидата наук і 20 без наукового ступеня. Усі доктори наук були в базі даних Web of Science Core Collection, i cepeднє значення індексу Хірша для їх групи становило приблизно 6,2 пункту. Серед кандидатів наук у базі даних був 31 науковець (75,6\% від загальної кількості із цим ступенем), а середнє значення індексу Хірша для їх групи становило майже 1,4 пункту (у 16 кандидатів наук цей індекс становив 0). У базі даних були також 8 науковців без наукового ступеня (40,0\% від загальної кількості без ступеня), проте середнє значення індексу Хірша для їх групи перевищувало 2,2 пункту (у 4 науковців цей індекс становив 0). У цілому по Інституту 57 науковців

* Адреса для листування (Correspondence): ДУ «Інститут ендокринології та обміну речовин ім. В.П. Комісаренка НАМН України», вул. Вишгородська, 69, м. Київ, 04114 ,

Україна. E-mail: pasteur@ukr.net

○ М.Д. Тронько, І.П. Пастер 
Оригінальні дослідження

(72,2\% від загальної кількості) були в базі даних Web of Science Core Collection і мали індекс Хірша, середнє значення якого дещо перевищувало 3,0 пункти. За всіма показниками беззаперечними лідерами $\epsilon$ науковці М.Д. Тронько та Т.І. Богданова, індекс Хірша яких становить відповідно 32 і 31 пункти. Висновок. У науковців Інституту є достатній потенціал для суттєвого поліпшення власних наукометричних показників за даними наукометричної бази Web of Science Core Collection.

Ключові слова: ДУ «Інститут ендокринології та обміну речовин ім. В.П. Комісаренка НАМН України», публікації науковців, наукометрична база даних Web of Science Core Collection, наукометричний аналіз.

На сьогодні Державна установа «Інститут ендокринології та обміну речовин ім. В.П. Комісаренка НАМН України» (далі - Інститут) є науковим, консультативним і лікувальним закладом, що надає допомогу дорослим і дітям із захворюваннями щитоподібної залози, цукровим діабетом та іншою ендокринною патологією. Також Інститут є провідною в Україні науково-дослідною базою для підготовки аспірантів, клінічних ординаторів, захисту докторських і кандидатських дисертацій за фахом «ендокринологія», підготовки фахівців на курсах стажування та інформації. Інститут виконує широке коло фундаментальних і прикладних науково-дослідних робіт, результати яких високо цінуються науковими співробітниками та практикуючими лікарями.

Водночас актуальною залишається проблема оцінки наукового внеску кожного співробітника Інституту [1]. Для цього використовують наукометричні показники, які розраховують за допомогою наукометричних баз даних. Кожна така база - це бібліографічна та реферативна база даних з інструментами для відстеження цитованості статей, опублікованих у наукових виданнях, із можливістю індексування посилань, зазначених у пристатейних списках цих публікацій, та розрахунку кількісних показників цих посилань. Завдяки таким базам можна оцінити продуктивність праці вченого та його вплив на світову науку, що опосередковано може свідчити про якість наукових досліджень.

Для оцінки результативності наукової діяльності вчених та організацій найчастіше використовують такі прості показники, як кількість опублікованих праць, загальна кількість їх цитувань і середня кількість цитувань на одну публікацію [2]. В основній праці з наукометрії зазначається, що оцінка діяльності вчених за сумарним числом публікацій завдає великої шкоди науці, оскільки з того, що талановиті вчені публікували багато праць, абсолютно не виходить протилежне: що будь-хто, який опублікував багато праць, $є$ талановитим ученим [3]. Отже, лише кількість публікацій не можна вважати критерієм ефективності вченого. Якщо прийняти за міру корисності публікації її цитованість, можна буде проводити порівняльну оцінку праць різних учених.

Зокрема, наукометрична база даних Web of Science (WoS) є базисом глобального електронного науково-інформаційного середовища Інституту наукової інформації (Information Sciences Institute) США, що сьогодні входить до складу корпорації Thomson Reuters [4]. Бази даних Інституту наукової інформації створювалися насамперед як пошукові, оскільки вони дають змогу проводити багатоаспектний пошук наукової літератури. Статистичні дані, представлені в цих базах, за своїм обсягом перевершують усі наявні дані подібного роду. На їх підставі стає можливим введення та використання важливих кількісних характеристик розвитку науки.

Власником наукометричної бази даних WoS є компанія Clarivate ${ }^{\mathrm{TM}}$ Analytics [5]. Назва Clarivate $^{\mathrm{TM}}$ походить від сполучення слів Clarify та Innovate - «Прояснення та інновації», що разом з Analytics - «Мистецтво аналізу» - є орієнтирами нової компанії.

Сьогодні WoS (Thomson Reuters) є платформою, на якій розміщено кілька баз даних [6]. Основною з них є WoS Core Collection (WoS CC) - реферативна наукометрична база даних, яка містить інформацію щодо видань та окремих публікацій (назву, авторів, установи, перелік літератури) та має технічні можливості підрахунку цитувань. Також у WoS CC є функція пошуку в пристатейній літературі, яка дозволяє оцінити, чи цитувалася та або інша праця або журнал у виданнях, проіндексованих на платформі [5].

Відомо, що наукометрична база даних - це бібліографічна та реферативна база даних з інстру- 
ментами для відстеження цитованості статей, опублікованих у наукових виданнях [7]. Проте наявність статті в одній із міжнародних баз ще не є підтвердженням її якості, важливими є ті кількісні показники, які цими системами розраховуються для кожної статті/автора/організації.

На жаль, наразі широко застосовується оцінка наукового доробку співробітника, колективу або організації за кількістю опублікованих статей, монографій, підручників, отриманих патентів тощо [8]. Тому й наукова діяльність зводиться до написання якомога більшої кількості рукописів низької якості, що надто легко зробити за умов формального рецензування редакціями спеціалізованих видань.

Для оцінки наукового внеску важливо усвідомлювати, що будь-яка бібліометрична база це механічна система, що опрацьовує інформацію зі списків бібліографічних посилань, порівнюючи нові надходження з уже наявними в системі [4]. Оскільки порівняння здійснюються автоматично, бібліографічні списки можуть працювати на наукометричні показники науковців або установ лише тоді, коли вони придатні до машинного розбору [9].

Раніше нами було виконано наукометричний аналіз публікаційної активності науковців Інституту за даними наукометричної бази даних Google Scholar [10].

Мета дослідження - наукометричний аналіз публікаційної активності науковців ДУ «Інститут ендокринології та обміну речовин ім. В.П. Комісаренка НАМН України» за даними наукометричної бази даних Web of Science Core Collection.

\section{Матеріал і методи}

Метод дослідження - наукометричний аналіз наукових публікацій за даними наукометричної бази даних Web of Science Core Collection. Об'єктом дослідження стали публікації науковців Інституту на платформі Web of Science Core Collection, а предметом дослідження - відповідні показники згідно з базою даних WoS CC за період із 1970 по 2019 рік:

«Кількість знайдених результатів» - кількість публікацій науковця;

«Індекс Хірша (h-індекс)» - найбільше значення h, коли h публікацій науковця мають принаймні h бібліографічних посилань;
«Середнє число посилань» - число бібліографічних посилань у середньому на одну публікацію науковця;

«Кількість посилань» - кількість бібліографічних посилань на публікації науковця;

«Кількість посилань без самоцитування» кількість бібліографічних посилань на публікації науковця без урахування посилань із цих публікацій;

«Кількість статей, які містять посилання на публікації» - кількість публікацій, які містять бібліографічні посилання на публікації науковця;

«Кількість статей, які містять посилання на публікації, без самоцитування» - кількість публікацій, які містять бібліографічні посилання на публікації науковця без урахування публікацій науковця.

\section{Результати та обговорення}

Станом на 01.11.2019 р. у штаті Інституту налічувалося 79 науковців, із них 18 із науковим ступенем доктора наук, 41 із науковим ступенем кандидата наук і 20 без наукового ступеня.

У групі науковців із науковим ступенем доктора наук (далі - доктор наук) спостерігалися дуже великі коливання між мінімальними та максимальними значеннями всіх показників (табл. 1). За всіма показниками беззаперечними лідерами є керівник відділу фундаментальних і прикладних проблем ендокринології Інституту, доктор медичних наук, професор, членкореспондент НАН України та академік НАМН України М.Д. Тронько та керівник лабораторії патоморфології Інституту, доктор біологічних наук, професор T.I. Богданова. Зокрема, індекс Хірша становить у них відповідно 32 і 31 пункти.

Серед науковців із науковим ступенем кандидата наук (далі - кандидат наук) явних лідерів немає, але за кількістю бібліографічних посилань на публікації науковця та кількістю публікацій, які містять бібліографічні посилання на публікації науковця, значний відрив є в кандидатів наук Терещенка В.П., Зурнаджи Л.Ю. та Замотаєвої Г.А. (табл. 2).

Серед науковців без наукового ступеня лідером є старший науковий співробітник Шпак В.M. (табл. 3).

У групі докторів наук усі показники (за винятком середнього числа посилань) є майже на порядок вищими, ніж відповідні показники в групі 
Оригінальні дослідження

кандидатів наук (табл. 4). Також останніх вдвічі випереджають науковці без наукового ступеня.

Усі доктори наук були в базі даних WoS CC, і середнє значення індексу Хірша для їх групи становило приблизно 6,2 пункту (табл. 5). Серед кандидатів наук у базі даних WoS CC був 31 науковець (75,6\% від загальної кількості із цим сту- пенем), а середнє значення індексу Хірша для їх групи становило майже 1,4 пункту (у 16 кандидатів наук цей індекс становив 0). У базі даних WoS СС були також 8 науковців без наукового ступеня (40,0\% від загальної кількості без ступеня), проте середнє значення індексу Хірша для їх групи перевищувало 2,2 пункту (у 4 науковців цей індекс

таблиця 1. Показники науковців Інституту з науковим ступенем доктора наук за даними Web of Sciences Core Collection за період 1970-2019 pp.

\begin{tabular}{|c|c|c|c|c|c|c|c|c|}
\hline \multirow[t]{2}{*}{$\begin{array}{l}\text { № } \\
3 / \Pi\end{array}$} & \multirow{2}{*}{$\begin{array}{l}\text { Прізвище } \\
\text { та ініціали } \\
\text { науковця }\end{array}$} & \multirow{2}{*}{$\begin{array}{l}\text { Загальна } \\
\text { кількість } \\
\text { знайдених } \\
\text { результатів }\end{array}$} & \multirow{2}{*}{$\begin{array}{l}\text { Індекс } \\
\text { Хірша } \\
\text { (h-index) }\end{array}$} & \multirow{2}{*}{$\begin{array}{l}\text { Середнє } \\
\text { число } \\
\text { цитувань }\end{array}$} & \multicolumn{2}{|c|}{ Кількість посилань } & \multicolumn{2}{|c|}{$\begin{array}{l}\text { Кількість статей } \\
\text { із посиланнями }\end{array}$} \\
\hline & & & & & загальна & $\begin{array}{l}\text { без само- } \\
\text { цитування }\end{array}$ & загальна & $\begin{array}{l}\text { без самоциту- } \\
\text { вання }\end{array}$ \\
\hline 1 & Тронько М.Д. & 187 & 32 & 16,84 & 3149 & 2810 & 1885 & 1792 \\
\hline 2 & Богданова Т.І. & 107 & 31 & 27,21 & 2911 & 2588 & 1612 & 1540 \\
\hline 3 & Резніков О.Г. & 57 & 9 & 4,42 & 252 & 196 & 191 & 172 \\
\hline 4 & Кравченко В.І. & 32 & 7 & 6,31 & 202 & 185 & 186 & 174 \\
\hline 5 & Кваченюк А.М. & 8 & 5 & 36,75 & 294 & 294 & 292 & 292 \\
\hline 6 & Зак К.П. & 56 & 4 & 0,95 & 53 & 32 & 46 & 31 \\
\hline 7 & Пушкарьов В.М. & 35 & 4 & 1,71 & 60 & 47 & 58 & 46 \\
\hline 8 & Божок B.M. & 20 & 3 & 1,65 & 33 & 22 & 30 & 22 \\
\hline 9 & Большова О.В. & 14 & 3 & 4,00 & 56 & 55 & 54 & 53 \\
\hline 10 & Корпачев В.В. & 25 & 3 & 5,00 & 125 & 122 & 111 & 108 \\
\hline 11 & Зінич О.В. & 4 & 2 & 27,00 & 108 & 106 & 94 & 92 \\
\hline 12 & Ковзун О.І. & 9 & 2 & 0,56 & 5 & 5 & 4 & 4 \\
\hline 13 & Болгов М.Ю. & 1 & 1 & 31,00 & 31 & 31 & 31 & 31 \\
\hline 14 & Калинська Л.М. & 12 & 1 & 0,42 & 5 & 1 & 4 & 1 \\
\hline 15 & Коваленко А.Є. & 4 & 1 & 0,50 & 2 & 2 & 2 & 2 \\
\hline 16 & Лучицький $\in$. В. & 30 & 1 & 0,20 & 6 & 6 & 6 & 6 \\
\hline 17 & Попова В.В. & 12 & 1 & 0,42 & 5 & 4 & 5 & 4 \\
\hline 18 & Соколова Л.К. & 1 & 1 & 0,50 & 4 & 4 & 4 & 4 \\
\hline
\end{tabular}

таблиця 2. Показники науковців Інституту з науковим ступенем кандидата наук за даними Web of Sciences Core Collection за період 1970-2019 pp.

\begin{tabular}{|c|c|c|c|c|c|c|c|c|}
\hline \multirow[t]{2}{*}{$\begin{array}{l}\text { № } \\
3 / \Pi\end{array}$} & \multirow{2}{*}{$\begin{array}{l}\text { Прізвище } \\
\text { та ініціали } \\
\text { науковця }\end{array}$} & \multirow{2}{*}{$\begin{array}{l}\text { Загальна кількість } \\
\text { знайдених } \\
\text { результатів }\end{array}$} & \multirow{2}{*}{$\begin{array}{l}\text { Індекс } \\
\text { Хірша } \\
\text { (h-index) }\end{array}$} & \multirow{2}{*}{$\begin{array}{l}\text { Середнє } \\
\text { число } \\
\text { цитувань }\end{array}$} & \multicolumn{2}{|c|}{ Кількість посилань } & \multicolumn{2}{|c|}{$\begin{array}{l}\text { Кількість статей } \\
\text { із посиланнями }\end{array}$} \\
\hline & & & & & загальна & $\begin{array}{l}\text { без само- } \\
\text { цитування }\end{array}$ & загальна & $\begin{array}{l}\text { без само- } \\
\text { цитування }\end{array}$ \\
\hline 1 & Терещенко В.П. & 13 & 8 & 27,23 & 354 & 336 & 245 & 236 \\
\hline 2 & Зурнаджи Л.Ю. & 15 & 7 & 14,33 & 215 & 204 & 181 & 173 \\
\hline 3 & Замотаєва Г.А. & 10 & 5 & 21,70 & 217 & 206 & 177 & 171 \\
\hline 4 & Терехова Г.м. & 10 & 5 & 10,60 & 106 & 97 & 84 & 77 \\
\hline 5 & Сімуров О.В. & 11 & 4 & 2,82 & 31 & 26 & 21 & 19 \\
\hline 6 & Тронько К.М. & 6 & 3 & 18,67 & 112 & 110 & 98 & 96 \\
\hline 7 & Орленко В.Л. & 7 & 2 & 15,43 & 108 & 106 & 94 & 92 \\
\hline 8 & Пастер І.П. & 15 & 2 & 6,93 & 104 & 104 & 104 & 104 \\
\hline 9 & Болгарська С.В. & 2 & 1 & 8,00 & 16 & 16 & 16 & 16 \\
\hline 10 & Зелінська Г.В. & 3 & 1 & 2,67 & 8 & 8 & 8 & 8 \\
\hline 11 & Левчук Н.І. & 2 & 1 & 1,00 & 2 & 2 & 2 & 2 \\
\hline 12 & Лукашеня О.С. & 1 & 1 & 2,00 & 2 & 2 & 2 & 2 \\
\hline 13 & Люткевич О.В. & 1 & 1 & 6,00 & 6 & 6 & 6 & 6 \\
\hline 14 & Пушкарьов В.В. & 3 & 1 & 2,67 & 8 & 8 & 8 & 8 \\
\hline 15 & Степура Н.М. & 2 & 1 & 0,50 & 1 & 1 & 1 & 1 \\
\hline
\end{tabular}

Примітки:у таблицю не включено науковців Інституту з вченим ступенем кандидата наук, публікації яких проіндексовано в базі даних WоS (CС) за період із 1970 по 2019 рік, проте індекс Хірша для яких дорівнює 0: Гончар І.В. (7 публікачій), Лучицький В.Є., Саєнко Я.А. (по 4), Гирявенко О.Я., Зубкова Г.А., Іваськіва К.Ю., Маліновська Т.М., Сачинська О.В., Шупрович А.А. (по 3), Сологуб Н.В. (2), Бельчіна Ю.Б., Гуда Б.Б., Ковальчук А.В., Кушнарьова Н.М., Фалюш О.А. і ХовакаВ.В. (по 1). 
Таблиця 3. Показники науковців Інституту без наукового ступеня за даними Web of Sciences Core Collection за період $1970-2019$ рр.

\begin{tabular}{|c|c|c|c|c|c|c|c|c|}
\hline \multirow[t]{2}{*}{ № $3 / \pi$} & \multirow{2}{*}{$\begin{array}{l}\text { Прізвище } \\
\text { та ініціали } \\
\text { науковця }\end{array}$} & \multirow{2}{*}{$\begin{array}{l}\text { Загальна кількість } \\
\text { знайдених } \\
\text { результатів }\end{array}$} & \multirow{2}{*}{$\begin{array}{l}\text { Індекс } \\
\text { Хірша } \\
\text { (h-index) }\end{array}$} & \multirow{2}{*}{$\begin{array}{l}\text { Середнє } \\
\text { число } \\
\text { цитувань }\end{array}$} & \multicolumn{2}{|c|}{ Кількість посилань } & \multicolumn{2}{|c|}{$\begin{array}{l}\text { Кількість статей } \\
\text { із посиланнями }\end{array}$} \\
\hline & & & & & загальна & $\begin{array}{l}\text { без само- } \\
\text { цитування }\end{array}$ & загальна & $\begin{array}{l}\text { без само- } \\
\text { цитування }\end{array}$ \\
\hline 1 & Шпак В.M. & 29 & 12 & 19,69 & 571 & 498 & 339 & 316 \\
\hline 2 & Полякова Л.І. & 8 & 3 & 3,13 & 25 & 23 & 24 & 23 \\
\hline 3 & Прибила О.В. & 2 & 2 & 54,00 & 108 & 106 & 94 & 92 \\
\hline 4 & Лузанчук І.A. & 1 & 1 & 10,00 & 10 & 10 & 10 & 10 \\
\hline
\end{tabular}

Примітки:у таблицю не включено науковців Iнституту без наукового ступеня, публікації яких проіндексовано в базі даних WoS (CC) за період із 1970 по 2019 рік, проте індекс Хірша для яких дорівнює О: Лимарева А.А. (5 публікачій), Куликовська Г.В. (3), Рибальченко В.М. (2) і Клочкова В.М. (1).

таблиця 4. Розподіл науковців Інституту за даними Web of Sciences Core Collection

\begin{tabular}{|c|c|c|c|c|c|}
\hline \multirow{2}{*}{$\begin{array}{l}\text { № } \\
3 / n\end{array}$} & \multirow[t]{2}{*}{ Показник } & \multicolumn{2}{|c|}{ Науковці з науковим ступенем } & \multirow{2}{*}{$\begin{array}{l}\text { Науковці без } \\
\text { наукового ступеня }\end{array}$} & \multirow[t]{2}{*}{ Усього } \\
\hline & & доктора наук & кандидата наук & & \\
\hline 1 & Загальна кількість науковців & 18 & 41 & 20 & 79 \\
\hline 2 & Кількість науковців у базі даних WoS CC & 18 & 31 & 8 & 57 \\
\hline 3 & Загальна кількість знайдених результатів & $34,1 \pm 11,0$ & $4,6 \pm 0,8^{*}$ & $6,4 \pm 3,3^{*}$ & $14,2 \pm 3,9$ \\
\hline 4 & Середнє число посилань & $9,2 \pm 2,9$ & $4,5 \pm 1,3$ & $10,8 \pm 6,6$ & $6,9 \pm 1,5$ \\
\hline 5 & Загальна кількість посилань & $405,6 \pm 226,2$ & $41,6 \pm 15,1$ & $89,2 \pm 70,0$ & $163,2 \pm 74,5$ \\
\hline 6 & Кількість посилань без самоцитування & $361,7 \pm 201,6$ & $39,7 \pm 14,4$ & $79,6 \pm 61,1$ & $147,0 \pm 66,4$ \\
\hline 7 & Загальна кількість статей із посиланнями & $256,4 \pm 129,8$ & $33,8 \pm 1,6$ & $58,4 \pm 41,7$ & $107,5 \pm 43,2$ \\
\hline 8 & $\begin{array}{l}\text { Кількість статей із посиланнями } \\
\text { без самоцитування }\end{array}$ & $243,0 \pm 123,8$ & $32,6 \pm 11,2$ & $55,1 \pm 38,9$ & $102,2 \pm 41,2$ \\
\hline
\end{tabular}

Примітки: * - p<0,05 відносно показника науковців із науковим ступенем доктора наук.

таблиця 5. Розподіл науковців Інституту за індексом Хірша за даними Web of Sciences Core Collection

\begin{tabular}{|c|c|c|c|c|c|}
\hline \multirow{2}{*}{$\begin{array}{l}\text { № } \\
3 / n\end{array}$} & \multirow[t]{2}{*}{ Показник } & \multicolumn{2}{|c|}{ Науковці з науковим ступенем } & \multirow{2}{*}{$\begin{array}{l}\text { Науковці без } \\
\text { наукового ступеня }\end{array}$} & \multirow[t]{2}{*}{ Усього } \\
\hline & & доктора наук & кандидата наук & & \\
\hline 1 & Загальна кількість науковців & 18 & 41 & 20 & 79 \\
\hline 2 & Кількість науковців у базі даних WoS CC iз h-index: & 18 & 31 & 8 & 57 \\
\hline 3 & 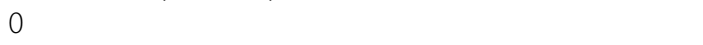 & 0 & 16 & 4 & 20 \\
\hline 4 & 1 & 6 & 6 & 1 & 13 \\
\hline 5 & 2 & 2 & 2 & 1 & 5 \\
\hline 6 & 3 & 3 & 2 & 1 & 6 \\
\hline 7 & 4 & 2 & 1 & 0 & 3 \\
\hline 8 & 5 & 1 & 2 & 0 & 3 \\
\hline 9 & $6-10$ & 2 & 2 & 0 & 4 \\
\hline 10 & $11-20$ & 0 & 0 & 1 & 1 \\
\hline 11 & $>20$ & 2 & 0 & 0 & 2 \\
\hline 12 & Середній h-index & $6,17 \pm 2,23$ & $1,39 \pm 0,39$ & $2,25 \pm 1,45$ & $3,02 \pm 0,80$ \\
\hline 13 & Медіана h-index & 3 & 0 & 0,5 & 1 \\
\hline 14 & Кількість науковців, які відсутні в базі даних WoS CC & 0 & 10 & 12 & 22 \\
\hline
\end{tabular}

становив 0). У цілому по Інституту 57 науковців (72,2\% від загальної кількості) були в базі даних WoS CC, а середнє значення індексу Хірша дещо перевищувало 3,0.

Оскільки в даному дослідженні рахували «довічний» індекс Хірша за майже всю наукову кар'єру (як було зроблено Х. Хіршем у вихідній статті), це призвело до певної нерівності літніх і молодих науковців Інституту.

Інтерпретація наукометричних показників: кількість статей - індикатор дослідницької (публікаційної) активності та показник наукової продуктивності, сумарна кількість цитувань та їх зіставлення в межах однієї предметної галузі показник наукового авторитету або впливовості; нормалізована середня цитованість - показник наукової ефективності [11, 12].

Про віднесення публікацій до авторів, організацій і країн слід пояснити ще один момент, пов'язаний зі співавторством [2]. Існує кілька способів підрахунку статей, написаних кількома авторами. Найпростіший із них - «повний рахунок», whole (aбo total) counting, який передбачає, що кожному зі співавторів зараховується по од- 
ній статті. Написав автор статтю самостійно або в співпраці з 20 колегами - це все одно плюс одна публікація в його статистиці.

Цей спосіб підрахунку загальної кількості публікацій науковців Інституту використано в даному дослідженні. Його відрізняє простота, проте слід пам'ятати, що він не забезпечує адитивність деяких показників [2].

Середня цитованість однієї статті оцінюе якість статті, ученого й організації в цілому [12]. Цитованість науковця впливає на його рейтинг і фінансування подальших проектів, а отже, і на цитованість установи, де він працює. Установа, в якій працює багато добре відомих і цитованих науковців - створювачів рейтингових публікацій, може впевнено розраховувати на підтримку держави та фінансових установ, участь бізнесових структур у прикладних розробках, зрештою - на залучення до подальших досліджень науковців із вищими рейтингами [13]. Вони зможуть обирати найвпливовіші у відповідній царині видання, принесуть нові високоцитовані публікації та, відповідно, гроші й стабільний поступ, сприятимуть створенню актуальних наукових шкіл і спадковості наукових традицій.

Для розрахунку реального показника середньої цитованості статті рекомендують застосовувати п’ятирічне публікаційне вікно й таке саме вікно цитування, оскільки коротший період не дозволить свіжим статтям набрати достатню кількість посилань, які повною мірою відображають їх науковий рівень [2]. 3 іншого боку, якщо зробити акцент на статтях, які вийшли давно, то не вдасться оцінити поточний стан досліджень автора.

У даному дослідженні встановлено максимально можливі публікаційне вікно та вікно цитування: 1970-2019 роки.

Кількість цитувань, або індекс цитування (сумарна цитованість) - це показник наукової впливовості, прийнятий у науковому світі показник «значущості» праць ученого [12]. Наявність в установі вчених, які мають високий індекс цитування, свідчить про високу ефективність і результативність діяльності наукового закладу в цілому.

Необхідно зазначити, що англійське «citation» означає не «цитування» або тим більше «цитату», а лише бібліографічне посилання [2]. Чіткіше варто говорити не про цитування, а про число отриманих посилань, «citation index» перекладати як «покажчик посилань». Проте в силу обмеженості мови, необхідності використовувати синоніми та сталої практики «цитування» еквівалентно «посиланню». Звичайно, не мається на увазі, що якщо одна стаття «цитує» іншу, то в першій міститься витяг, фрагмент із другої (те, що позначається англійським словом «quotation»). Мова лише про те, що друга стаття фігурує в списку використаної літератури першої статті.

На цитованість публікації впливає низка чинників, які не мають безпосереднього відношення до її наукового рівня: царина науки, рік видання (що раніше видано статтю, то більше посилань вона могла отримати до моменту вимірювання), тип публікації (у середньому, наприклад, наукові огляди цитуються частіше, ніж оригінальні дослідницькі статті) [2].

Індекс Хірша (h-index) - це наукометричний показник, який $є$ кількісною характеристикою продуктивності вченого, групи вчених, установи або країни в цілому [12]. Простота розрахунків зробила індекс Хірша популярним наукометричним показником. Індекс Хірша було розроблено, аби отримати більш адекватну оцінку наукової продуктивності дослідника, ніж можуть дати такі прості характеристики, як загальна кількість публікацій / загальна кількість цитувань. Індекси Хірша, розраховані в різних базах, будуть різнитись. Індекс Хірша добре працює лише для порівняння вчених, які працюють в одній галузі досліджень, оскільки традиції, пов'язані із цитуванням, різняться в різних галузях науки (наприклад, у біології та медицині індекс Хірша набагато вищий, ніж у фізиці).

Механізм розрахунку індексу Хірша такий: учений має індекс h, якщо $\mathrm{h}$ із його $\mathrm{Np}$ праць мають кількість цитувань більшу або рівну $\mathrm{h}$ кожна, а інші праці $(\mathrm{Np}-\mathrm{h})$ мають кількість цитувань меншу, ніж h кожна [4, 14]. Тобто, учений з індекcoм h має h (або більше) публікацій, кожну з яких процитовано h (або більше) разів. Отже, якщо перелік праць ученого оформити у вигляді списку, ранжованого за цитованістю (від найбільш до найменш цитованих), індекс $\mathrm{h}$ буде обмежений останньою в списку працею, порядковий номер якої в списку є меншим, ніж кількість її цитувань, або дорівнює кількості цитувань. Індекс Хірша $\epsilon$ кількісною характеристикою продуктивності вченого за весь період наукової діяльності. Як i будь-який формальний показник, індекс h має свої переваги та недоліки.

Для досягнення високого значення індексу Хірша необхідно, аби автор писав багато праць, 
кожна з яких отримувала б багато цитувань [2]. Саме в цьому сенсі індекс Хірша намагається відобразити збалансовану оцінку одразу й активності публікацій вченого, і цитованості його праць.

До істотних недоліків індексу Хірша відносять те, що він не враховує кількість співавторів у публікаціях (що має велике значення у зв'язку з постійним зростанням кількості співавторів і появою статей, кількість авторів в яких вимірюється тисячами), не може зменшуватися в часі (тобто фактичне припинення активної наукової діяльності ніяк не впливає на зміну вже досягнутого показника), є за визначенням цілим числом (знижується точність виміру), не враховує тип документа, особливості цитування в різних наукових галузях тощо [2]. Для компенсації зазначених недоліків на сьогодні розроблено вже близько сотні різних варіацій індексу Хірша.

Оскільки двоє науковців Інституту мають трикратний відрив від решти за індексом Хірша, що значно впливає на середні величини, коректно провести порівняння за показником медіани замість середнього. Встановлено, що середнє значення індексу Хірша в групі науковців із науковим ступенем доктора наук становить 6,2, а медіана -3 (див. табл. 5). Приблизно така ж різниця між цими двома показниками є характерною i для інших груп науковців і для всіх науковців Інституту в цілому.

Необхідно також враховувати, що на всі розглянуті показники впливають і цитування, зроблені самими «досліджуваними об'єктами» на себе [2]. Не можна сказати, що облік самоцитування - це недолік розрахунку або, навпаки, його сильний бік. Необхідно знати про цю особливість і брати її до уваги. Корисно порівнювати показники, пораховані з включеним самоцитуванням і $з$ виключеним.

Загалом включення в аналіз праць ученого всіх посилань, які $є$ «самоцитуванням співавторів», пропонує досить ригористичний підхід: порахуємо лише цитування, отримані з «геть чужих» праць, безліч авторів яких ніяк не перетинається з безліччю авторів цитованої публікації [2].

Загалом саме по собі самоцитування, звичайно, не лише не порочна практика, але навіть невід'ємна складова наукової комунікації [2]. Складно уявити собі автора, який би не посилався на свої попередні праці, - це був би вчений, який або постійно міняє царину діяльності, або соромиться, відрікається від своїх колишніх пу- блікацій. Але не можна і не пам'ятати про можливі зловживання, коли самоцитування гіпертрофується та спотворює бібліометричний аналіз, якщо в ньому не відстежувати даний аспект.

Також варто звернути увагу на проблему «множинності» авторів - коли в одного науковця існує до десятка варіантів транслітерації прізвища [5]. Витоки проблеми полягають у зміні стандартів транслітерації, використанні різними ресурсами різних правил i, звісно, помилок авторів, усе це унеможливлює автоматичну ідентифікацію окремого автора.

Наприклад, пошук публікацій Лучицького Є.B. за базою WoS CC дав такі варіації:
Luchitskii
Luchytskiy
Luchitskiy
Luchitsky
Luchytskii
Luchytskyi
Luchytsky
Luchytskyy

Для коректного вирішення цього питання варто скористатися послугами сайту Державного підприємства «Документ», де онлайн-транслітерація прізвища та імені здійснюється шляхом відтворення кожної літери латиницею згідно 3 транслітераційною таблицею, яка складається з транслітераційних пар, де пара - це кирилична літера і відповідна до неї латинична літера, що мають однакову або подібну вимову [15]. Офіційну транслітерацію українського алфавіту латиницею затверджено Постановою Кабінету Міністрів України № 55 від 27 січня 2010 року, і згідно з нею вірно: Luchytskyi.

$\mathrm{y}$ наукових статтях та інших наукових публікаціях для їх індексування в наукометричних системах має велике значення афіліація («Affiliation», організація та іï місцезнаходження) [16]. Вірне зазначення місця роботи автора дозволяє правильно ідентифікувати його та виключити ймовірність втрати публікаційних показників окремих авторів, які мають поширене прізвище, а також показників цитованості установ, де їх афілійовано. За успішністю автора (насамперед за цитуванням його статей) визначається успішність організації, де він працює. Афіліацію в статтях має бути представлено так, аби її можна було легко та точно ідентифікувати й опрацювати автоматичними засобами, як і всі інші дані статті.

Особливу увагу видання мають звертати на зазначення назв установи [5]. Крім того, що історично назви та підпорядкованість установ змінювалися, автори (або редактори), вказуючи назву 
інституції, часто перекладають іiї на власний розсуд, не беручи до уваги або не знаючи офіційної назви англійською. Інколи назву установи офіційно не закріплено. Наприклад, для Одеського національного університету імені I.I. Мечникова в публікаціях у WoS CC знайдено 75 варіацій назви. Порівнянні або більші цифри отримуємо для усіх великих університетів.

Назва Інституту також має декілька варіацій, зокрема:

Inst Endocrinol

Inst Endocrinol Metab

Inst Endocrinol \& Metab

Inst Endocrinol \& Metab NAMS Ukraine

Kiev Endocrinol Metab Res Inst

Komisarenko Inst Endocrinol \& Metab

Це саме стосується і відомчого підпорядкування:

NAMS Ukraine

Natl Acad Med Sci Ukraine

Ukraine Acad Med Sci

Ukrainian Academy of Medical Sciences

Кожен із таких записів, кожна афіліація - це окремий профіль, за яким здійснюється підрахунок показників публікаційної активності та цитованості. [16]. Звісно, це ускладнює підрахунок здобутків установи та може призвести до викривлення результатів [5].

Коректна афіліація Інституту:

V.P. Komisarenko Institute of Endocrinology and Metabolism, National Academy of Medical Sciences of Ukraine, 69, Vyshhorodska str., Kyiv, 04114, Ukraine.

Натомість навіть коректне виконання умов транслітерації прізвища та імені, зазначення назви та підпорядкованості установи не гарантуе правильності результатів пошуку, про що попереджають на сайті [17].

Аби автори могли представити всі свої праці з урахуванням змін місця роботи та прізвища, було запропоновано авторські ідентифікатори ORCID, ResearcherID тощо [5].

ORCID - ідентифікатор науковця - його онлайн Curriculum vitae, яке дає змогу представити праці науковця та інформацію про його кар'єрні здобутки, отримані гранти тощо, є «поєднувачем» між різними базами та ресурсами й вимагається від усіх авторів у дедалі більшій кількості міжнародних видань $[5,18]$.

ResearcherID - безкоштовний продукт компаніï Clarivate Analytics, дає змогу науковцю представити всі власні публікації, а для тих, що індексуються WoS CC, - проаналізувати цитування та розрахувати індекс Хірша [5, 19]. Станом на 2017 рік за кількістю створених профілів ResearcherID Україна посідала 19-е місце у світі, понад 13670 українських науковців зареєструвалися в системі, проте лише частина з них додали власні публікації, дозаповнили свій профіль, вказали тематику наукових досліджень та назву установи.

На жаль, просто створення профілю не допоможе збільшити видимість результатів ученого обов'язково необхідно додати публікації [5]. Це можна зробити, розмістивши публікації в преінстальованій теці My publication референс-менеджера EndNote, або експортувати записи з WoS чи з ORCID.

Необхідно стимулювати авторів створювати, наповнювати й підтримувати в актуальному стані власні профілі в ResearcherID та ORCID, що дозволить коректно ідентифікувати вже наявні й подальші публікації з конкретним науковцем та організаціями, де він працює, розмістити інформацію про публікації в професійних мережах науковців, наприклад ResearchGate [6, 16]. За наявності доступу до WoS науковим установам потрібно створити в цій базі власні профілі.

Користуватися платформою $\mathrm{WoS}$ без реєстрації можна з будь-якого комп'ютера з мережі установи, яка має передплату. Але якщо науковець створить власний кабінет, він отримає не лише розширені можливості збереження, пошуку та шанс користуватися продуктами поза межами установи, але й зручний перехід до власного референс-менеджера EndNote base та авторського профілю ResearcherID, логін і пароль буде спільним для всіх продуктів $[6,20]$.

Варто зазначити, що наукометричний аналіз показав лише 1 науковця Інституту, який оформив ResearcherID і ORCID (доктор наук B.M. Пушкарьов), i 6 науковців, які оформили ORCID (доктори наук М.Д. Тронько, О.Г. Резніков, Т.I. Богданова, К.П. Зак, В.В. Попова, кандидат наук І.П. Пастер).

Наразі найреальнішим тактично є розширення міжнародного співробітництва, що збільшує як частку міжнародних публікацій, так і можливість публікацій українських авторів у рейтингових міжнародних журналах [2]. Ефективним також може виявитися розширення практики публікації наукових результатів у журналах від- 
критого доступу або використання опції відкритого доступу в журналах із гібридною моделлю публікації. Відкритий доступ потенційно сприяє швидшому цитуванню наукових статей, тобто справляє суттєвий вплив на показники цитованості, що використовуються для складання рейтингів університетів.

На думку головних редакторів найвпливовіших у світі журналів, яку підтверджують інформаційні матеріали WoS i Scopus, саме огляд зараз $\epsilon$ тим типом публікацій, на який здійснюється найбільше посилань, тобто огляди є найцитованішими у світі матеріалами [13]. Щоправда, нині оглядом вважають розлогу публікацію з певного актуального напряму досліджень із понад сотнею посилань на джерела, опубліковані щонайбільше п'ять років тому.

На рівні конкретної установи можливими є такі напрямки, що сприяють як підвищенню публікаційної активності, так і ліпшому поданню наукових результатів установи в міжнародних індексах цитування [2]:

а) адміністративні заходи:

- сувора регламентація зазначення назви установи як місця роботи автора в публікаціях, що дозволить уникнути помилок і неточностей в індексації публікацій установи;

- введення вимог щодо наявності публікацій для проходження конкурсів на заміщення посад науково-педагогічних працівників, що дозволяє підвищувати рівень кадрового складу.

б) стимулюючі заходи:

- встановлення доплат або преміювання залежно від кількості публікацій у міжнародних базах, їх цитування;

- компенсація оплати публікацій відкритого доступу в рейтингових журналах тощо;

- підвищення кваліфікації науково-педагогічних працівників, навчання аспірантів і студентів засадам академічного письма, використання електронних ресурсів і наукометричних інструментів для планування своєї наукової діяльності.

в) інфраструктурні заходи:

- розширення передплати на електронні ресурси, що дозволяє вченим знайомитися з найактуальнішою науковою інформацією та планувати напрямки своїх досліджень відповідно до світових трендів;

- модернізація наукового обладнання тощо. Важливість стимулювання публікаційної ді- яльності та підвищення публікаційної активності підтверджує й зростання в геометричній прогресії у світі кількості публікацій (статей, методичних рекомендацій, моніторингових розвідок), а також різних семінарів, практикумів, вебінарів, присвячених цим питанням [13].

Керівництвом багатьох вітчизняних наукових установ запроваджено додаткові фінансові заохочення для авторів публікацій із метою стимулювання росту наукової продуктивності та відображення іiї результатів у наукометричних ресурсах [21]. Так, має місце практика преміювання науковців за публікації в закордонних періодичних виданнях, які індексуються базами даних WoS, Scopus (Київський університет імені Бориса Грінченка), за публікації у виданнях з імпакт-фактором понад 1 (Харківський національний університет імені В.Н. Каразіна), відповідно до рівня видання за імпакт-фактором (Сумський державний університет) і відповідно до імпактфактора журналу та наукометричної бази даних Scopus (Чернівецький національний університет імені Юрія Федьковича) [22].

Водночас потрібно пам'ятати, що наукометричні дані є лише допоміжними індикаторами в оцінці наукового доробку, а перше правило знаменитого Лейденського маніфесту, який пропонує десять принципів коректного використання наукометрії, вчить, що не можна підміняти експертну оцінку кількісною [21, 23]. Так, 16 грудня 2012 року на щорічній конференції Американського товариства клітинної біологіï (American Society for Cell Biology) у СанФранциско було прийнято Декларацію про оцінювання наукових досліджень (San Francisco Declaration on Research Assessment) [24]. Вона закликає наукову громадськість відмовитися від використання імпакт-факторів для визначення результативності діяльності вчених і дослідницьких колективів, оскільки місія науки - отримання нових знань, а не маніпулювання цифрами. Незважаючи на деякі переваги експертної оцінки порівняно з наукометричними показниками, основним її недоліком є суб'єктивність [8].

Проте зважене використання наукометричних показників у процесі оцінки наукового доробку співробітника, колективу або організації за кількістю публікацій у виданнях, що індексуються в міжнародних наукометричних базах, теоретично здатне позитивно вплинути на зростання їх наукової продуктивності [21, 23]. 


\section{Висновки}

1. Публікації57 науковців ДУ «Інститут ендокринології та обміну речовин ім. В.П. Комісаренка НАМН України» проіндексовано в базі даних Web of Science Core Collection.

2. Кількість проіндексованих публікацій у 49 науковців Інституту становить від 1 до 25 одиниць, у 4 науковців - від 26 до 50, у 2 науковців - від 51 до 75 і у 2 науковців - понад 100.

3. Три науковці Інституту мають індекс Хірша 32, 31 і 12, 4 науковці - від 6 до 10 і 30 науковців - від 1 до 5.

4. Середнє число цитувань в 1 науковця Інституту становить 54 одиниці, у 5 науковців - від 26 до 50, у 6 науковців - від 11 до 25, у 6 науковців - від 6 до 10 і в 19 науковців - до 5 .

5. Кількість бібліографічних посилань у 3 науковців Інституту становить 3149, 2911 і 571 одиницю, у 3 науковців - від 251 до 500, у 10 науковців - від 101 до 250, у 3 науковців - від 51 до 75, у 3 науковців - від 26 до 50 і в 15 науковців - від 1 до 25.

6. Кількість статей із бібліографічними посиланнями у 2 науковців Інституту становить 1885 і 1612 одиниць, у 2 науковців - від 251 до 500, у 7 науковців - від 101 до 250, у 5 науковців - від 76 до 100, у 2 науковців - від 51 до 75, у 3 науковців - від 26 до 50 і в 16 науковців від 1 до 25.

7. У науковців Інституту є достатній потенціал для суттєвого поліпшення власних наукометричних показників у базі даних Web of Science Core Collection.

\section{Список використаної літератури}

1. Савіна РВ, Волощук ОВ, Коркач ВС, Мельченко ЮВ. Наукометричний аналіз публікаційної активності фахівців ДУ «Інститут громадського здоров'я ім. О.М. Марзєєва НАМН України» у виданнях, що входять до міжнародних баз даних. Довкілля та здоров'я. 2017; (2):68-71. (Savina RV, Voloshchuk OV, Korkach VS, Melchenko YuV. Scientometric analysis of publication activity of the specialists of SI «O.M. Marzeiev Institute for public health, National Academy of Medical Sciences of Ukraine» in the editions including in the international data bases. Dovkillya ta zdorov'ya. 2017; (2):68-71).

2. Акоев МА, Маркусова ВА, Москалева ОВ, Писляков ВВ. Руководство по наукометрии: индикаторы развития науки и технологии (под. ред. Акоева М.А.). Екатеринбург: Изд-во Урал. ун-та, 2014. 250 c. (Akoyev MA, Markusova VA, Moskaleva OV, Pislyakov VV. Handbook for scientometrics: indicators of science and technology development. (Edited by Akoyev M.A.). Ekaterinburg: Ural University Publishing House, 2014. 250 p.).

3. Налимов ВВ, Мульченко 3М. Наукометрия. Изучение развития науки как информационного процесса. М.: Наука. 1969; 192 с. (Nalimov VV, Mulchenko ZM. Scientometrics. Studying the development of science as an information process. Moscow: Nauka. 1969;192 p.).
4. Костенко ЛЙ, Жабін ОI, Копанєва СО, Симоненко ТВ. Наукова періодика України та бібліометричні дослідження. НАН України, Нац. б-ка України ім. B.I. Вернадського, Київ. 2014; 212 с. (Kostenko LI, Zhabin OI, Kopanyeva EO, Symonenko TV. Scientific periodicals of Ukraine and bibliometric study. NAS of Ukraine, V.I. Vernadsky National Library of Ukraine, Kyiv. 2014;212 p.).

5. Тихонкова IO. Критерії та процедура відбору журналів до Web of Science Core Collection. Наука України у світовому інформаційному просторі. Київ: Академперіодика. 2017; 14: 93-105. (Tykhonkova IO Criteria and journals selection process to the Web of Science Core Collection. Science of Ukraine in the Global Information Space. Kyiv: Akademperiodyka. 2017;14:93-105).

6. Тихонкова IO. Наукова періодика України у дзеркалі Web of Science. Наука України у світовому інформаційному просторі. Київ: Академперіодика. 2016;13:31-9. (Tykhonkova IO. Ukrainian journals in the Web of Science. Science of Ukraine in the Global Information Space. Kyiv: Akademperiodyka. 2016;13:31-9).

7. Єрмаков СС. Проблеми та перспективи публікації статті в українському журналі, що входить до зарубіжної наукометричної бази. Вiсник Чернігівського національного педагогічного університету. Серія: Педагогічні науки. Фізичне виховання та спорт. 2013;112(2):104-12. (Yermakov SS. Problems and prospects of Ukrainian publishing an article in a journal that is a foreign scientific metric base. Herald of Chernihiv National Pedagogical University. Series: Pedahohichni nauky. Fizychne vykhovannya ta sport. 2013;112(2):104-12).

8. Дзяк ГВ, Потоцкая ОЮ. Российский индекс научного цитирования как оптимальная наукометрическая база для анализа украинской научной периодики. Морфологія. 2013;7(3):127-37. (Dzyak GV, Pototska OYu. Russian index of scientific citation as the optimal scientometric database for the integration of Ukrainian scientific periodicals. Morpholohia. 2013;7(3):127-37).

9. Радченко AI. Про перший міжнародний семінар «Підготовка наукових журналів до індексування в аналітичних інформаційних системах SCIVERSE SCOPUS та PIHЦ SCIENCE INDEX: проблеми та рішення». Наука України у світовому інформаційному простоpi. 2011; 5:40-8. (Radchenko AI. About the first international seminar «Preparation of scientific journals for indexing in analytical information systems SCIVERSE SCOPUS and RISC SCIENCE INDEX: problems and solutions». Nauka Ukrayiny u svitovomu informatsiynomu prostori. 2011;5:40-8).

10. Тронько МД, Пастер ІП. Наукометричний аналіз публікаційної активності науковців ДУ «Інститут ендокринології та обміну речовин ім. В.П. Комісаренка НАМН України» за даними наукометричної бази даних Google Scholar. Ендокринологія. 2019;24(1):46-52. (Tronko MD, Pasteur IP. A scientometric analysis of the publication activity of scientists in State Institution «V.P. Komisarenko Institute of Endocrinology and Metabolism, Natl. Acad. Med. Sci. of Ukraine» based on data from scientometric database of Google Scholar. Endokrynologia. 2019;24(1):46-52).

11. Назаровець С. Наукометричні ресурси: у допомогу проведення та представлення наукових досліджень (Nazarovets S. Scientometric resources: to help realization and present scientific research) http://ekmair.ukma.edu.ua/bitstream/handle/123456789/3015/ scientometrics.pdf

12. Чернівецький національний університет імені Юрія Федьковича Наукова бібліотека ЧНУ. Послуги та сервіси. На допомогу науковцю. Наукометричні показники. (Yuriy Fed'kovych Chernivtsi National University. National Library of Science. Services and services. To the aid of the scientist. Scientometric indicators) http://library.chnu.edu. ua/?page $=/$ ua/07services/04helpsci/0101scimetrics

13. Діденко ЮВ, Радченко А.І. Публікаційна активність як спосіб наукової комунікації та гонитви за рейтингами. Вісн. НАН України. 2017;9:82-98. (Didenko YuV, Radchenko AI. Publication activity as a way of scientific communication and ratings race. Visn. Nac. Acad. Nauk Ukr. 2017;9:82-98).

14. Hirsch JE. An index to quantify an individual's scientific research output. Proc Natl Acad Sci USA. 2005 Nov;102(46):16569-72.

15. Державне підприємство «Документ». Онлайн транслітерація прізвища та імені. (The State Enterprise «Document». Online transliteration of name and surname) https://pasport.org.ua/vazhlivo/transliteratsiya

16. Діденко ЮВ, Радченко АI, Коваль НВ. Інформаційна система Web of Science: дзеркало чи інструмент? Наука та інновації. 2016;12(6) 75-84. (Didenko YuV, Radchenko AI, Koval NV. Information system Web of Science: mirror or tool. Nauka ta innovatsii. 2016;12(6):75-84). 
17. Web of Science. Author Search. https://app.webofknowledge.com/ author/\#/search? SID=D5BQ79V2zF9NmGqHpvV

18. ORCID. https://orcid.org/

19. ResearcherID. http://www.researcherid.com/\#rid-for-researchers

20. Тихонкова IO. Список літератури наукової статті - важливий індикатор якості статті (як не мати зайвого клопоту з його оформленням). Наука України у світовому інформаційному просторі. Київ: Академперіодика, 2015;11:100-6. (Tykhonkova IO. References are the important indicator of articles quality. How to escape an extra work. Science of Ukraine in the Global Information Space. Kyiv Akademperiodyka, 2015;11:100-6).

21. Назаровець С. Квартильний підхід до проблеми стимулювання росту наукової продуктивності в університетах. Бібліотечний форум: історія, теорія і практика. 2016;2(4):10-2. (Nazarovets C. A quartile approach to the problem of stimulating the growth of scientific productivity in universities. Library forum: history, theory and practice. 2016;2(4):10-2).

22. Назаровець С. Квартильний підхід до проблеми стимулювання публікаційної активності українських науковців (Nazarovets C. A quartile approach to the problem of stimulating the publishing activity of Ukrainian scientists). http://ekmair.ukma.edu.ua/bitstream/handle/123456789/7269/nazarovets_stymul.pdf?sequence=1\&isAllowed=y

23. Hicks D, Wouters P, Waltman L, de Rijcke S, Rafols I. Bibliometrics: The Leiden Manifesto for research metrics. Nature. 2015 Apr;520(7548):429-31.

24. San Francisco Declaration on Research Assessment. https://sfdora.org/ read

(Надійшла до редакиії 15.11.2019 р.)

\section{Наукометрический анализ публикационной активности ученых ГУ «Институт эндокринологии и обмена веществ им. В.П. Комиссаренко НАМН Украины» по данным наукометрической базы данных Web of Science}

\section{Н.Д. Тронько, И.П. Пастер}

ГУ «Институт эндокринологии и обмена веществ имени В.П. Комиссаренко НАМН Украины»

Резюме. Цель - наукометрический анализ публикационной активности ученых ГУ «Институт эндокринологии и обмена веществ им. В.П. Комиссаренко НАМН Украины» (дальше - Институт) по данным наукометрической базы данных Web of Science. Материал и методы. Метод исследования - наукометрический анализ научных публикаций по данным наукометрической базы данных Web of Science Core Collection. Объектом исследования стали все публикации ученых Института за данными Web of Science Core Collection, а предметом исследования — количество публикаций, индекс Хирша (h-индекс), количество библиографических ссылок на публикации и количество статей с библиографическими ссылками на публикации (общее количество и количество без самоцитирования). Результаты. По состоянию на 01.11.2019 г. в штате Института насчитывалось 79 ученых, из них 18 имели научную степень доктора наук, 41 - кандидата наук и 20 ученых не имели научной степени. Bсе доктора наук были в базе данных Web of Science Core Collection, и среднее значение индекса Хирша для их группы составляло приблизительно 6,2 пункта. Среди кандидатов наук в базе данных был 31 ученый (75,6\% от общего количества с этой степенью), а среднее значение индекса Хирша для их группы составляло почти 1,4 пункта (у 16 кандидатов наук этот индекс составлял 0). В базе данных были также 8 ученых без научной степени (40,0\% от общего количества без степени), однако среднее значение индекса Хирша для их группы превышало 2,2 пункта (у 4 ученых этот индекс составлял 0). В целом по Институту 57 ученых (72,2\% от общего количества) были в базе данных Web of Science Core Collection и имели индекс Хирша, среднее значение которого несколько превышало 3,0 пункта. По всем показателям безоговорочными лидерами являются ученые Н.Д. Тронько и Т.И. Богданова, индекс Хирша которых составляет соответственно 32 и 31 пункт. Вывод. У ученых Института имеется достаточный потенциал для существенного улучшения собственных наукометрических показателей по данным наукометрической базы Web of Science Core Collection.

Ключевые слова: ГУ «Институт эндокринологии и обмена веществ им. В.П. Комиссаренко НАМН Украины», публикации ученых, наукометрическая база данных Web of Science Core Collection, наукометрический анализ

A scientometric analysis of the publication activity of scientists in State Institution «V.P. Komisarenko Institute of Endocrinology and Metabolism, Natl. Acad. Med. Sci. of Ukraine» based on data from scientometric database of Web of Science

\section{M.D. Tronko, I.P. Pasteur}

SI «V.P. Komisarenko Institute of Endocrinology and Metabolism, Nat. Acad. Med. Sci. of Ukraine», Kyiv, Ukraine

Abstract. The aim - a scientometric analysis of the publication activity of scientists in the State Institution «V.P. Komisarenko Institute of Endocrinology and Metabolism, Natl. Acad. Med. Sci of Ukraine» (hereinafter referred to as the Institute) according to the scientometric database Web of Science. Material and methods. The method for studying is a scientometric analysis of scientific publications according to the Web of Science database. The object of the study was all the publications of the Institute scientists according to the Web of Science Core Collection, and the subject of the study was the number of publications, the Hirsch index (h-index), the number of bibliographic references to publications and the number of articles with bibliographic references to publications (total and non-cited number). Results. As of November 1, 2019, the Institute had 79 scientists, of whom 18 had a doctoral degree, 41 had a PhD, and 20 had no scientific degree. All doctors of science were in the Web of Science Core Collection database and the average value of the Hirsch index for their group was approximately 6.2 points. Among the candidates of sciences, there were 31 scientists in the database $(75.6 \%$ of the total number with this degree), and the average value of the Hirsch index for their group was almost 1.4 points (this index was 0 for 16 candidates of science). There were also 8 scientists without a scientific degree ( $40.0 \%$ of the total number without a degree) in the database, however, the average value of the Hirsch index for their group exceeded 2.2 points (in 4 scientists this index was 0 ). In general, at the Institute, 57 scientists (72.2\% of the total number) were in the Web of Science Core Collection database and had a Hirsch index, the average value of which slightly exceeded 3.0 points. In all respects, the undisputed leaders are scientists such as Tronko N.D. and Bogdanova T.I., whose Hirsch index is 32 and 31 points, respectively. Conclusion. The scientists of the Institute have sufficient potential for a significant improvement of their own scientometric indicators according to the Web of Science Core Collection database.

Keywords: SI «V.P. Komisarenko Institute of Endocrinology and Metabolism, Nat. Acad. Med. Sci. of Ukraine», publication of scientists, sciencebased database Web of Science Core Collection, scientometric analysis. 